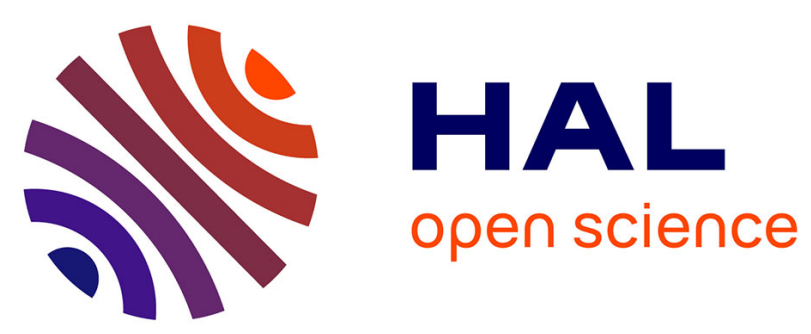

\title{
Factors controlling plasticity of leaf morphology in Robinia pseudoacacia L. II: the impact of water stress on leaf morphology of seedlings grown in a controlled environment chamber
}

\author{
Zhang, Maria Equiza, Zheng, Melvin Tyree
}

\section{To cite this version:}

Zhang, Maria Equiza, Zheng, Melvin Tyree. Factors controlling plasticity of leaf morphology in Robinia pseudoacacia L. II: the impact of water stress on leaf morphology of seedlings grown in a controlled environment chamber. Annals of Forest Science, 2012, 69 (1), pp.39-47. 10.1007/s13595011-0134-7 . hal-00930705

\section{HAL Id: hal-00930705 \\ https://hal.science/hal-00930705}

Submitted on 1 Jan 2012

HAL is a multi-disciplinary open access archive for the deposit and dissemination of scientific research documents, whether they are published or not. The documents may come from teaching and research institutions in France or abroad, or from public or private research centers.
L'archive ouverte pluridisciplinaire HAL, est destinée au dépôt et à la diffusion de documents scientifiques de niveau recherche, publiés ou non, émanant des établissements d'enseignement et de recherche français ou étrangers, des laboratoires publics ou privés. 


\title{
Factors controlling plasticity of leaf morphology in Robinia pseudoacacia $L$. II: the impact of water stress on leaf morphology of seedlings grown in a controlled environment chamber
}

\author{
Yanxiang Zhang • Maria Alejandra Equiza • \\ Quanshui Zheng $\cdot$ Melvin T. Tyree
}

Received: 23 May 2011 / Accepted: 26 August 2011 / Published online: 22 September 2011

(C) INRA and Springer Science+Business Media B.V. 2011

\begin{abstract}
- Context The cause of morphological plasticity of leaves within the crowns of tall trees still debated. Whether it is driven by irradiance or hydraulic constraints is inconclusive. In a previous study, we hypothesized that water stress caused between-site and within-tree morphological variability in mature Robinia trees.

- Aims To test this hypothesis, we designed an experiment to analyze the effect of long-term water stress on leaf growth of Robinia seedlings in a controlled environment.
\end{abstract}

Handling Editor: Erwin Dreyer

Contribution of the co-authors Yanxiang ZHANG: did the experimental work, data analysis, and first draft.

Maria Alejandra EQUIZA: provided training in methods and oversaw experimental work.

Quanshui ZHENG: was primary $\mathrm{PhD}$ supervisor in China.

Melvin T. TYREE: suggested experimental design and assisted in writing and data analysis.

Y. Zhang $\cdot$ Q. Zheng

Department of Engineering Mechanics, Tsinghua University,

Beijing 100084, China

Y. Zhang $\cdot$ M. A. Equiza $\cdot$ M. T. Tyree

Department of Renewable Resources, 444 ESB,

University of Alberta,

Edmonton, AB, Canada T6G 2E3

M. T. Tyree $(\bowtie)$

Northern Research Station, U.S. Forest Service,

705 Spear St.,

S. Burlington, VT 05403, USA

e-mail: mtyree@fs.fed.us

M. T. Tyree

e-mail: mttyree@gmail.com
- Methods Two treatments were performed: well-watered (midday water potential, $\Psi_{\mathrm{w}}=-0.45 \mathrm{MPa}$ ) and waterstressed $\left(\Psi_{\mathrm{w}}=-1.0 \mathrm{Mpa}\right)$, which resulted in significant differences in physiology, relative growth rate, and the temporal progress of leaf growth.

- Results Variation of leaf cell sizes among treatments was comparable to the variability previously observed in the field. However, values of leaf density and leaf mass per unit area tended to be lower in our controlled experiments than in the field, which may reflect differences between mature leaves of juvenile and adult trees.

- Conclusions Our tentative conclusion is that leaf water stress may be the primary factor controlling morphological changes observed in the field, but further experiments are needed to document the relative importance of irradiance.

Keywords Leaf growth · Water stress · Temporal evolution $\cdot$ Tree height

\section{Introduction}

The plasticity of leaf morphology within the canopy profile of trees has received increased attention (Sack et al. 2006; Cavaleri et al. 2010; Oldham et al. 2010). The debate recently has been over the relevance of irradiance versus height (hydraulic constraint) as the primary determinant of the plasticity (Ellsworth and Reich 1993; Sack et al. 2006; Marshall and Monserud 2003; England and Attiwill 2006; Cavaleri et al. 2010; Oldham et al. 2010). Since almost a century ago, the study of leaf morphology and its response to environmental factors such as irradiance, vapor pressure deficits, temperature, and relative humidity has been studied 
(Hanson 1917). Previous studies have shown that leaves developed under higher irradiance levels have longer and stacked palisade cells and larger and more abundant mesophyll cells, which results in increased leaf thickness and leaf dry weight per area (LMA) (Ellsworth and Reich 1993; Hikosaka et al. 1994). Based on these previous studies, the plasticity of leaf morphology along tree height has been assumed to be mainly irradiance-driven (Ellsworth and Reich 1993; Sack et al. 2006). However, increasing recent evidence is suggesting that leaf morphological plasticity in tree canopies is much more strongly related to hydrostatic constraints than to irradiance (Marshall and Monserud 2003; Koch et al. 2004; England and Attiwill 2006; Cavaleri et al. 2010; Oldham et al. 2010). Water potential declines due to hydrostatic (gravity-induced) and hydrodynamic resistance in tall trees (e.g., Tyree and Zimmermann 2002; Woodruff et al. 2004), which reduces the turgor pressure necessary for cell expansion and, as a consequence, affects the size and morphological characteristics of the leaf.

Changes in both cell division and cell expansion can underlie the leaf morphological plasticity observed along a tree's vertical gradient. In dicotyledonous species, two developmental phases have been identified during leaf expansion (Lecoeur et al. 1995; Pereyra-Irujo et al. 2008; Granier and Tardieu 2009). In the first phase, leaf size can be described by an exponential function with time and leaf growth coordinates cell division and tissue expansion, absolute growth rate $(G R)$ is slow, and relative growth rate $(R G R)$ is high (Pothig and Sussex 1985). In the second phase, cell division slows down and individual cell area increases resulting in tissue expansion at a high $G R$ (Granier and Tardieu 1998). Previous studies on different dicotyledonous crop species (Lecoeur et al. 1995; Granier and Tardieu 1999, 2009) have shown that water stress reduces both GR and RGR resulting in smaller final leaf area and higher leaf LMA.

Our experimental data from adult Robinia trees in the field (Paper I of this series) showed a significant morphological plasticity of leaves along the vertical tree canopy, with leaves on the top of the crown being smaller and thicker than those at the bottom. Our data also suggested that leaf morphology and anatomy were more associated with hydraulic constraints than with irradiance, because of significant differences in morphology between wet and dry sites at comparable heights. In the present study, two levels of water stress imposed on seedlings in controlled environments were used to mimic hydraulic constraints at the top of Robinia trees. This kind of experimental approach, which we have previously applied to study height-related hydraulic constraints in a conifer species (Zhang et al. 2011), has been used to isolate the effect of water potential gradients from other environmental gradients that would normally occur across the canopy of a tree (e.g., irradiance, temperature, and relative humidity). The present study will focus on the effect of long-term water stress on the growth of one dicotyledonous woody species-Robinia pseudoacacia L., with the aim to assess if mild water stress in Robinia seedlings will result in morpho-anatomical changes similar to those previously observed in adult trees $<16 \mathrm{~m}$ tall in the field.

In this study, we analyzed the effects of water stress on temporal changes of leaf growth, cell expansion, and division during the development of Robinia leaves experiencing stable, long-term mild water stress compared with well-watered controls. We also compared the results in this study and the results in the field in paper I of this series and confirmed the effects of hydraulic constraints on leaf morphological plasticity along tree height.

\section{Materials and methods}

Experiments were conducted in a growth chamber at the University of Alberta from April to July 2010. The daily photoperiod was $18 \mathrm{~h}$ (from 600 to 2400 hours) with artificial light provided by $400-\mathrm{W}$ xenon lamps. Maximum photosynthetic photon flux density was $350 \mu \mathrm{mol} \mathrm{m} \mathrm{m}^{-2}$. Temperature was kept at $22^{\circ} \mathrm{C} / 18^{\circ} \mathrm{C}$ (day/night) and relative humidity at $75 \%$.

Twenty-four $R$. pseudoacacia $L$. seedlings were grown in 2-L pots filled with a potting mix composed of peat moss (55$65 \%$ ), perlite, dolomitic limestone, and gypsum (Sunshine ${ }^{\circledR}$ LA4 mix, Sun Grow Horticulture Canada Ltd.). Lateral stems were removed as soon as they became visible so all measurements were taken on upper terminal shoots. During the first month, all seedlings were kept well watered. Thereafter, two watering regimes were imposed for 90 days: (1) well-watered (midday $\Psi_{\mathrm{w}}$ was around $-0.45 \mathrm{MPa}$ ), (2) water-stressed (midday $\Psi_{\mathrm{w}}$ was kept around $-1.00 \mathrm{MPa}$ ) (Table 1). The difference of water potential between these two treatments was kept around $0.5 \mathrm{MPa}$, which is the difference of water potential at the top and bottom of Robinia trees in the field based on our experimental data in paper I of this series.

Table 1 Summary of water potential $\Psi_{\mathrm{w}}(\mathrm{MPa})$, net photosynthesis $\left(\mu \mathrm{mol} \cdot \mathrm{CO}_{2} \cdot \mathrm{m}^{-2} \mathrm{~s}^{-1}\right)$, and stomatal conductance $g_{\mathrm{s}}\left(\mathrm{mol} \cdot \mathrm{m}^{-2} \mathrm{~s}^{-1}\right)$ in the two treatments: control and drought

\begin{tabular}{lccc}
\hline Variables & Control & Drought & $P$ value \\
\hline Water potential & $-0.483 \pm 0.0919 \mathrm{a}$ & $-1.011 \pm 0.021 \mathrm{~b}$ & $<0.001$ \\
Net photosynthesis & $7.363 \pm 0.382 \mathrm{a}$ & $1.652 \pm 0.133 \mathrm{~b}$ & $<0.001$ \\
Stomatal conductance & $0.186 \pm 0.0414 \mathrm{a}$ & $0.021 \pm 0.00108 \mathrm{~b}$ & $<0.001$
\end{tabular}

Different letters behind the values indicate significant difference between treatments $(P<0.05)$. Values are means \pm SE. Each mean value was the average value of 12 plants per treatment 
Twelve seedlings per treatment were used. The surface of the containers of all water-stressed plants was covered with aluminum paper to limit evaporation from the soil. Plants were $100-110 \mathrm{~cm}$ tall and with about $8 \mathrm{~mm}$ basal-stem diameter at the start of the treatments.

During the first week of the two treatments, midday stomatal conductance $\left(g_{\mathrm{s}}\right)$ was measured daily using a portable open-flow photosynthesis system (LI-6400, Li-Cor, Inc) equipped with a LI-6400B red/blue LED light source. Once leaves acclimated to the conditions within the chamber $\left(\mathrm{CO}_{2} 386 \mu \mathrm{mol} \mathrm{mol}^{-1}\right.$, air temperature $21 \pm 0.15^{\circ} \mathrm{C}$, and VPD $1.3 \pm 0.3 \mathrm{kPa}$, PPFD $500 \mu \mathrm{mol}$ photon $\mathrm{m}^{-2} \mathrm{~s}^{-1}$ ), data were logged every $30 \mathrm{~s}$ during a 5 -min period. The average of the ten measurements obtained for each plant was used for data analysis. Midday leaf water potential $\Psi_{\mathrm{w}}$ was measured every other day using a pressure bomb (Soil Moisture Equipment Corp., Santa Barbara, USA) until it reached the selected targets. As soon as the target stress levels were reached, the weight was recorded for each pot in the late afternoon. Targets were subsequently maintained by adding water to each pot on a daily basis at 1800 hours to restore the previous day's weight. On typical days, the amount of water added was $130 \mathrm{~g}$ per 2-L pot for each drought plant. Midday $\Psi_{\mathrm{w}}$ and $g_{\mathrm{s}}$ were assessed once per week until the end of the experiment to confirm that target stress level was properly maintained.

\subsection{Growth measurements}

Since the effect of water deficit depends largely on the timing of the treatment, relative to the development of the leaf (Granier and Tardieu 1999), all the samples were selected from the new leaves budded from the terminal meristem after all the treatments were at the target stress levels. Measurements of length of the main petiole of the compound leaf and length and width of the fourth leaflet from each compound leaf were started when leaves were about $1 \%$ of final leaf length and leaflet area, respectively. Preliminary experiments indicated that $1 \%$ final size (leaf length and leaflet area) occurred when leaves were $2.75 \mathrm{~mm}$ and $10.4 \mathrm{~mm}^{2}$ for controls and $2.00 \mathrm{~mm}$ and $6.05 \mathrm{~mm}^{2}$ for stressed plants, respectively. Leaf length was defined as the distance from a mark made at the base of the petiole to the base of the terminal leaflet of the odd pinnate compound leaves of Robinia. Daily measurements of leaf length were performed with a ruler while leaflet length and width were measured with a digital caliper until leaf growth ceased. A highly significant linear relationship $\left(r^{2}>0.99, n=192, P<0.0001\right)$ was established between length $\times$ width and leaflet area, which was applicable to any leaf regardless of leaf number, leaf age, or treatment. The fourth pair of leaflets from the base of the compound leaves and three consecutive leaves per plant was selected for the leaf growth measurements. Based on our preliminary experiment (not shown), leaf final size was not related to leaf sequence on the stem when tree height was taller than $0.8 \mathrm{~m}$. The duration of both leaf and leaflet growth was defined as the number of days from the moment of $1 \%$ of final leaf length and leaflet area to the moment of $95 \%$ of final leaf length and leaflet area was reached. $G R$ was calculated as the slope of the relationship between length $(L)$ and time $(t)$ in two consecutive measurements, and $R G R$ was calculated as the slope of the relationship between the logarithm of length $(L)$ and time (t): $G R=[\mathrm{d}(L) / \mathrm{d} t]$ and $R G R=[\mathrm{d}(\ln (L)) / \mathrm{d} t]$, and similar equations are applied for leaflet area (Pereyra-Irujo et al. 2008).

Six to eight leaflets (the fourth leaflet from the base of leaf) per plant were chosen for laboratory measurement of leaflet area and leaflet dry weight. An image of each leaflet was scanned by a scanner, and then leaflet area was calculated using the software ImageJ (Image Processing and Analysis in Java; http://rsb.info.nih.gov/ij/). Thereafter, these leaflets were dried in an oven at $70^{\circ} \mathrm{C}$ for $48 \mathrm{~h}$ and then weighed to determine dry weight and $L M A$ ( $L M A=$ dry weight/leaflet area). Leaflet density was equated to $L M A$ /leaflet thickness. Leaf thickness was not measured every time LMA was calculated so thickness measurements were sometimes interpolated from plots of thickness verus $\%$ final leaf length by using a polynomial fit.

\subsection{Leaf anatomical measurements}

Leaflet paraffin sections were made at 5\%, 10\%, 25\%, $50 \%$, and $100 \%$ of final leaf length. For each growth point, two leaflets per plant, 12 plants per treatment, were selected for sections. All the subsamples for sections were picked from the middle base (about $6 \times 6 \mathrm{~mm}$ ) of each fresh leaflet. Samples were fixed in FAA (95\% ethanol/glacial acetic acid/ formalin/distilled water=10:1:2:7), dehydrated in ethanol series and embedded in paraffin. Cross sections, 6- $\mu \mathrm{m}$ thick, were stained with safranin O-fast green and mounted in DPX. Images were obtained with a digital camera (Infinity1-5C, Regent Instruments Inc., Quebec, Canada) mounted on a microscope (Axioskop 40, Zeiss, Jena, Germany). Leaflet thickness, first-layer palisade mesophyll cells (located immediately under upper epidermis), cell length and width, and upper and lower epidermal cell width and thickness were calculated using the software ImageJ.

\subsection{Data analysis}

Data were analyzed with one-way ANOVA. Differences of mean values between treatments were separated by Tukey's HSD Test with 95\% confidence level. 


\section{Results}

\subsection{Leaf physiology and growth}

The water stress imposed in this experiment induced a significant reduction in net photosynthesis $(77 \%$ reduction compared to controls) and stomatal conductance $(88 \%$ reduction) (Table 1).

Leaflet number per compound leaf was similar for controls and stressed plants, $21.58 \pm 0.48$ and $21.23 \pm 0.29$ for control and drought, respectively $(P=0.918$; data not shown). Leaf and leaflet growth were significantly affected by water stress (Fig. 1). The GR and RGR were significantly reduced under water stress. Water stress affected the duration of growth phases. The first phase (1\% to $25 \%$ final length) included days 1 to 15 in controls and 1 to 20 in stressed plants; the second phase ( $25 \%$ to $95 \%$ final length) included days 16 to 30 in controls and 21 to 40 in stressed plants.

\subsection{LMA and leaflet density}

During leaf growth, $L M A$ and leaflet density changed significantly at all phases of growth expressed as the leaflength ratio (the ratio of growing leaflet area to final leaflet area, Fig. 2). $L M A$ increased markedly before $25 \%$ of final leaf length and then dropped a bit during leaf rapid growth ( $25 \%$ to $95 \%$ of final leaf length) (Fig. 2a). Leaflet density increased rapidly until a peak at around $10 \%$ of the final leaf length, and then it dropped at a constant rate $(10 \%$ to $95 \%$ of final leaf length) (Fig. 2b). At maturity, both $L M A$ and density increased (100\% of final leaf length). During leaf growth, $L M A$ was always greater in water-stressed than in well-watered plants (Fig. 2a). Similar to $L M A$, leaf density was higher for stressed plants during leaf development (Fig. 2b).

\subsection{Leaflet anatomical structure}

During leaf growth, leaflet palisade mesophyll and epidermal cell size showed significant variation between treatments (Figs. 3 and 4). Leaflet thickness increased with leaf age, but it was always greater in water-stressed plants than in controls $(P<0.001$; Fig. 4a). The length of first-layer palisade mesophyll cells increased with leaf age regardless of the treatment. At maturity, water-stressed plants had longer palisade mesophyll cells than controlled plants, although before maturity, the length was smaller $(P<0.001$; Fig. $4 b)$. The width of the first-layer palisade cells did not show variation with time, and it was always smaller in the waterstressed plants $(P<0.001$; Fig. 4b). Epidermal cell width and thickness increased with leaf age. While epidermal cell width was smaller under water stress $(P<0.001$; Fig. 4c), epidermal cell thickness did not exhibit a consistent trend between treatments during leaf growth (Fig. 4d).

During leaf growth, epidermal and palisade mesophyll cell number per leaf cross-sectional area decreased with leaf age (Table 2). At 5\% of final leaf length, epidermal and palisade mesophyll cell number per cross-sectional area were smaller under water stress than controls $(P<0.001)$. At $10 \%$ and $25 \%$ of final leaf length, cell number per cross
Fig. 1 Temporal changes in leaf length (a), leaf growth rate $(G R)$ (b), leaf relative growth rate $(R G R)(\mathbf{c})$, leaflet area (d), leaflet $G R$ (e) and leaflet $R G R$ (f). Vertical lines indicate the moment at which $95 \%$ of final leaf length and final leaflet area are reached in well-watered (solid line) and water-stressed plants (dashed line) (a, d). Each value was the average of 12 plants per treatment. Bars indicate $\mathrm{S}$. E
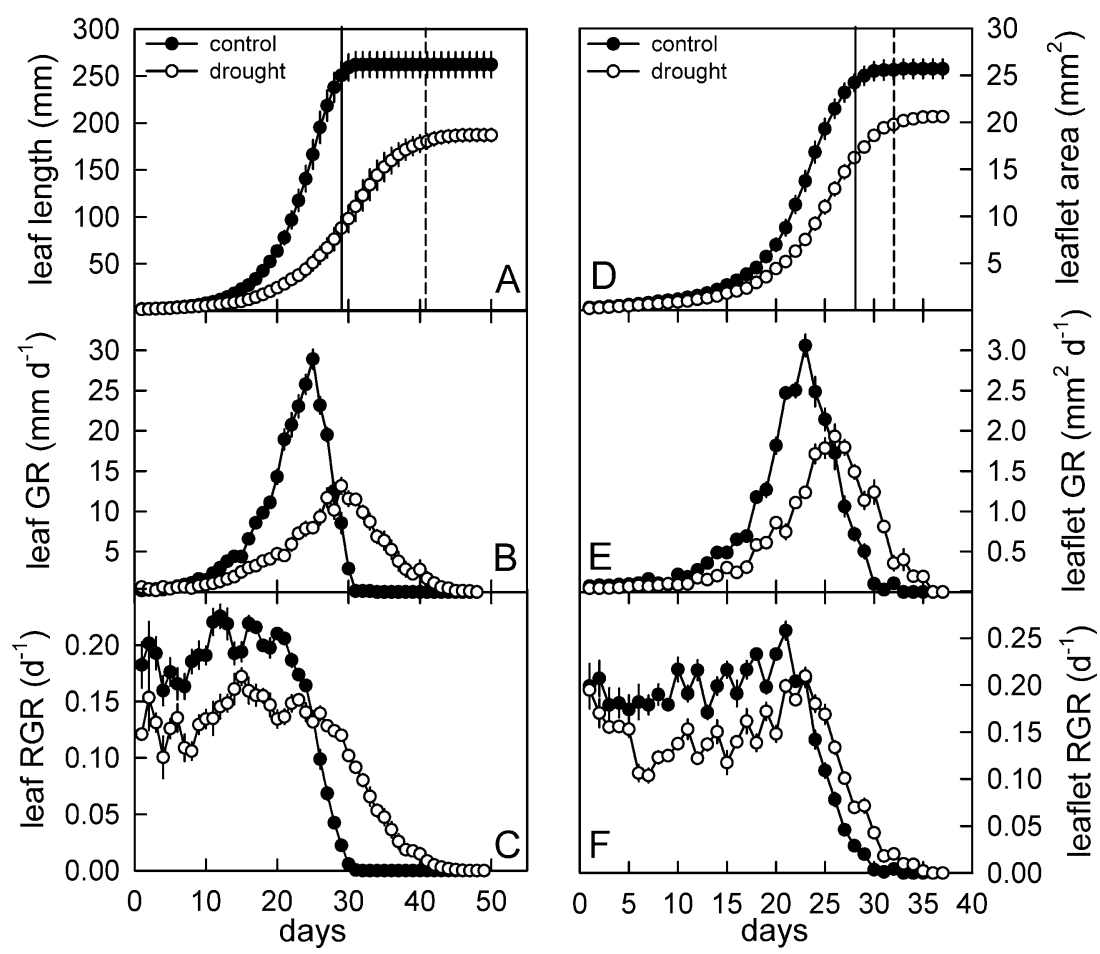


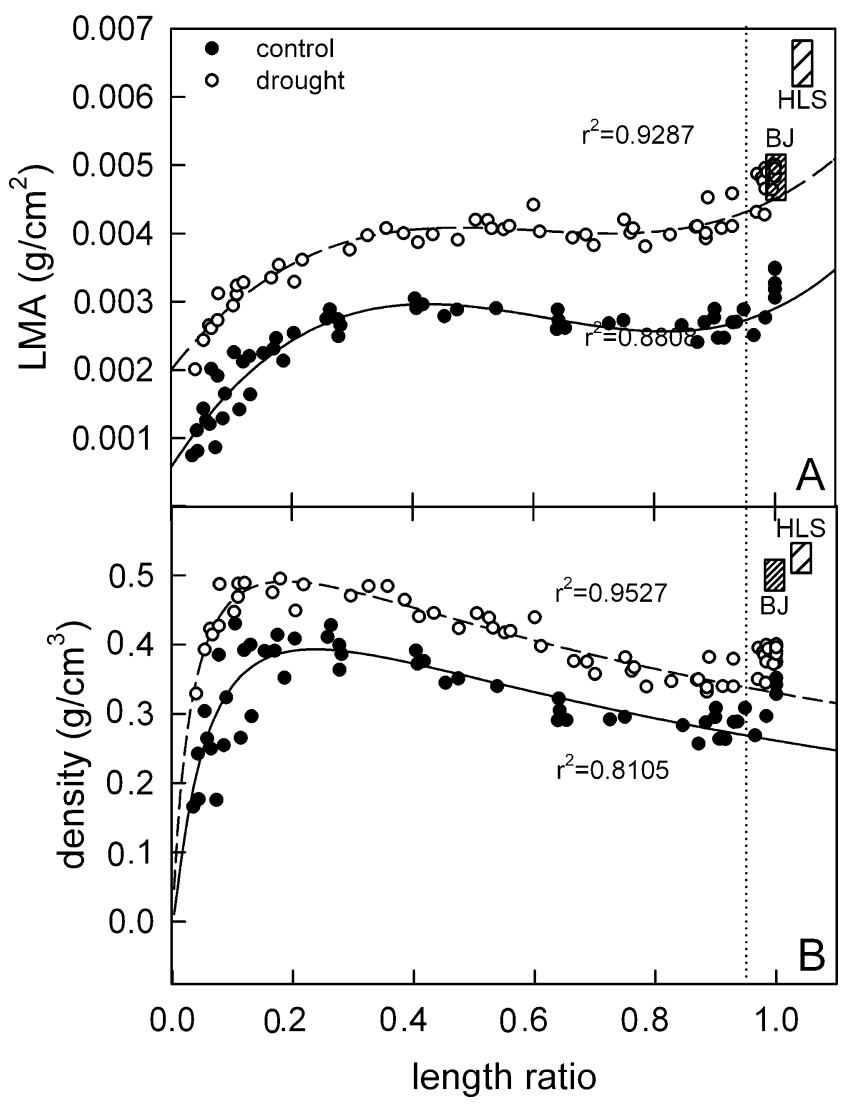

Fig. 2 Changes in LMA (a) and leaf density (b) during leaf development, expressed as leaf-length ratio. Length ratio is the ratio of growing leaflet area to final leaflet area. The vertical dotted line indicates $95 \%$ of final leaf length. Regression functions were fit for the data from $1 \%$ to $95 \%$ of final leaf length. $\mathrm{r}^{2}$ is shown in the plot for each fit function. Field observations from mature trees in sites BJ (Beijing Forestry University) and HLS (Helan Mountain) are indicated by vertical bars for comparison (paper I of this series)

area did not differ significantly between treatments while at $50 \%$ of final leaf length, both epidermal and mesophyll cell number per cross area under water stress was significantly greater than controls $(P<0.01)$. However, at $100 \%$ of final leaf length, only epidermal cell number was significantly reduced under water stress.

\section{Discussion}

There has been a growing interest in the factors influencing leaf morphology within the crown of large trees. Recent published reports have been appropriate in terms of scope and design for ecological studies, i.e., determining the range of variation among diverse species and using statistical approaches to find correlations that help one to hypothesize the underlying mechanisms that might account for the variation. In this regard, there have been some notable large-scale survey studies: (1) Sack et al. (2006) analyzed six deciduous species growing in an arboretum, (2) Cavaleri et al. (2010) surveyed a wide range of neo-tropical species of varying growth form (herbaceous, palms, epiphytes, trees, and lianas), (3) Oldham et al. (2010) focused on some of the largest known trees (Sequioia sempervirens). The "independent" factors that have been assessed include height, position in the canopy (inner versus outer), and irradiance, and these have been correlated statistically with one or more "dependent" variables such as leaf mass per unit area, some measure of leaf size (length, width, area, and/or thickness), or more cellularscale measures (cuticles, stomates, mesophyll porosity, or cell size). The limitation of the statistical approaches used (maximum likelihood analysis or principle component analysis) relates to the conundrum that the independent variables identified might be interdependent through a third independent parameter and that a statistical analysis does little to address the underlying mechanisms that result in the plasticity of leaf morphology. We argue that both light and height combine to influence water potential which, in turn, controls growth and leaf morphology. For example, while Cavaleri et al. (2010) concluded that height is more important than light, Sack et al. (2006) concluded that light more than height determines leaf morphology. However, the latter study makes passing reference to a complicating factor: "The exposed leaves may also be 'stunted' by the irradiance and/or by the associated higher temperature and vapor pressure deficits, which might reduce leaf water status." This point deserves more attention.

Light ( $I=$ net irradiance) and height $(h)$ might not be totally independent if a major independent factor influencing leaf morphology turns out to be water stress. A simple soilplant-atmosphere continuum model can be used to explain the interrelatedness of height and light (Tyree 1999).

$\Psi_{\mathrm{w}}=\Psi_{\text {soil }}-\rho g h-E(I) / R_{\mathrm{p}}$,

where $\Psi_{\mathrm{w}}$ is the water potential of a growing leaf, $\Psi_{\text {soil }}$ is the water potential of the soil when the leaf is growing, $\rho$ is the density of water, $g$ is the acceleration due to gravity, $E$ is the evaporative flux density, and $R_{\mathrm{p}}$ is the hydraulic path resistance from the soil to any given developing leaf. Equation 1 might be usefully interpreted in terms of the Lockhart growth model (Lockhart 1965).

$\mathrm{RGR}=m\left(\Psi_{\mathrm{p}}-Y\right)=m\left(\Psi_{\mathrm{w}}+\Psi_{\pi}-Y\right)$,

where $R G R$ is the relative growth rate, $\Psi_{\mathrm{p}}$ is the turgor pressure driving growth, $Y$ is the yield point, and $m$ is the cell wall extensibility. In terms of water potential, $\Psi_{\mathrm{w}}=\Psi_{\mathrm{p}}+\Psi_{\pi}$ where $\Psi_{\pi}$ is the osmotic potential. Diurnally $\Psi_{\pi}$ remains relatively constant between day and night in plant cells because $90 \%$ to $98 \%$ of the change in $\Psi_{\mathrm{p}}$ is attributed to change in $\Psi_{\mathrm{w}}$. This follows because $\Psi_{\pi}$ is inversely proportional to cell volume, and cell volume changes only a few percent diurnally. The only exception is when osmotic adjustments occur in some species in response to long-term water stress, where 

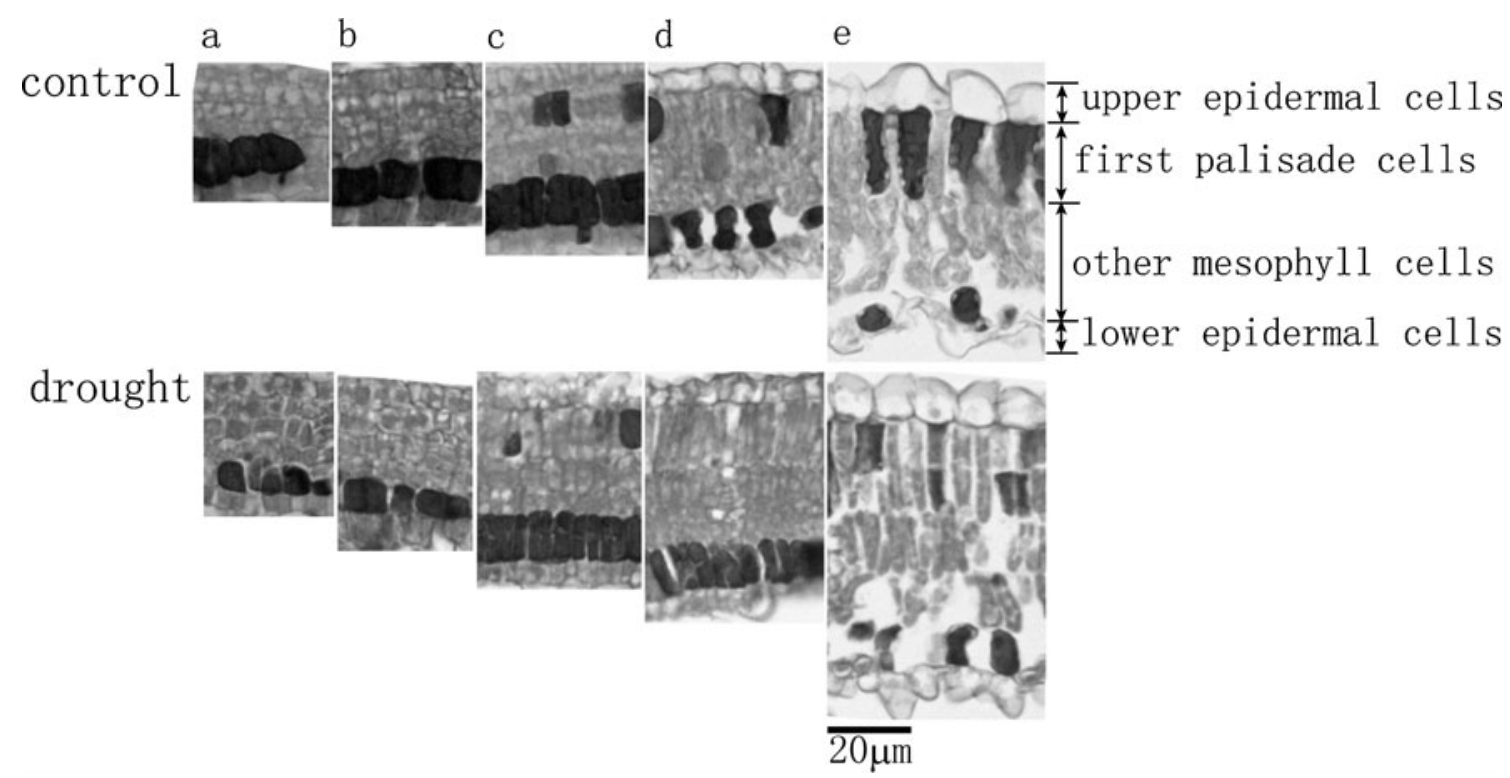

Fig. 3 Leaflet anatomy in control and drought treatments at five growth points: $5 \%$ (a), $10 \%$ (b), $25 \%$ (c), $50 \%$ (d) and 100\% (e) of final leaf length. Cells were divided into four types from upper side of

persistently low $\Psi_{\mathrm{w}}$ can induce a change in $\Psi_{\pi}$ which is still thought be constant diurnally under persistent water stress.

Equation 2 describes only the impact of $\Psi_{\mathrm{w}}$ or $\Psi_{\mathrm{p}}$ on instantaneous growth rate whereas final leaf and cell size will depend on the integral of Eq. 2 over the entire period of growth which in the case of Robinia is 30 to 40 days in our study and typical of that in other woody species (Meinzer et al. 2008). While this paper does not parame- leaf to lower side: upper epidermal cells, first palisade mesophyll cells, other mesophyll cells, and lower epidermal cells

terize $m$ and $Y$ in Eq. 2, this is the subject of the third paper in this series. But it is obvious from Eq. 1 that height and light co-contribute to $\Psi_{\mathrm{w}}$.

Water stress $\left(\Psi_{\mathrm{w}}\right)$ is co-influenced by soil water stress, height, and $E$; $E$ in turn is a function of $I$, which is the intended meaning of $E(I)$ in Eq. 1. Evaporative flux rate depends on the energy needed to vaporize liquid water, and the majority of the energy is derived from net radiation. Hence, $E$ is often a linear function of $I$ (Tyree 1999). The
Fig. 4 Leaflet thickness (a), width and length of first-layer palisade mesophyll cells (b), width (c), and thickness (d) of upper epidermal cells at five growth points: $5 \%, 10 \%, 25 \%$, $50 \%$, and $100 \%$ of final leaf length. Each mean value at each growth point was the average of 12 trees. Different letters above the error bars indicate significant differences between treatments $(P<0.05)$. Bars indicate SE. Field observations from mature trees in sites $B J$ (Beijing Forestry University) and HLS (Helan Mountain) are indicated by vertical bars for comparison (paper I of this series)

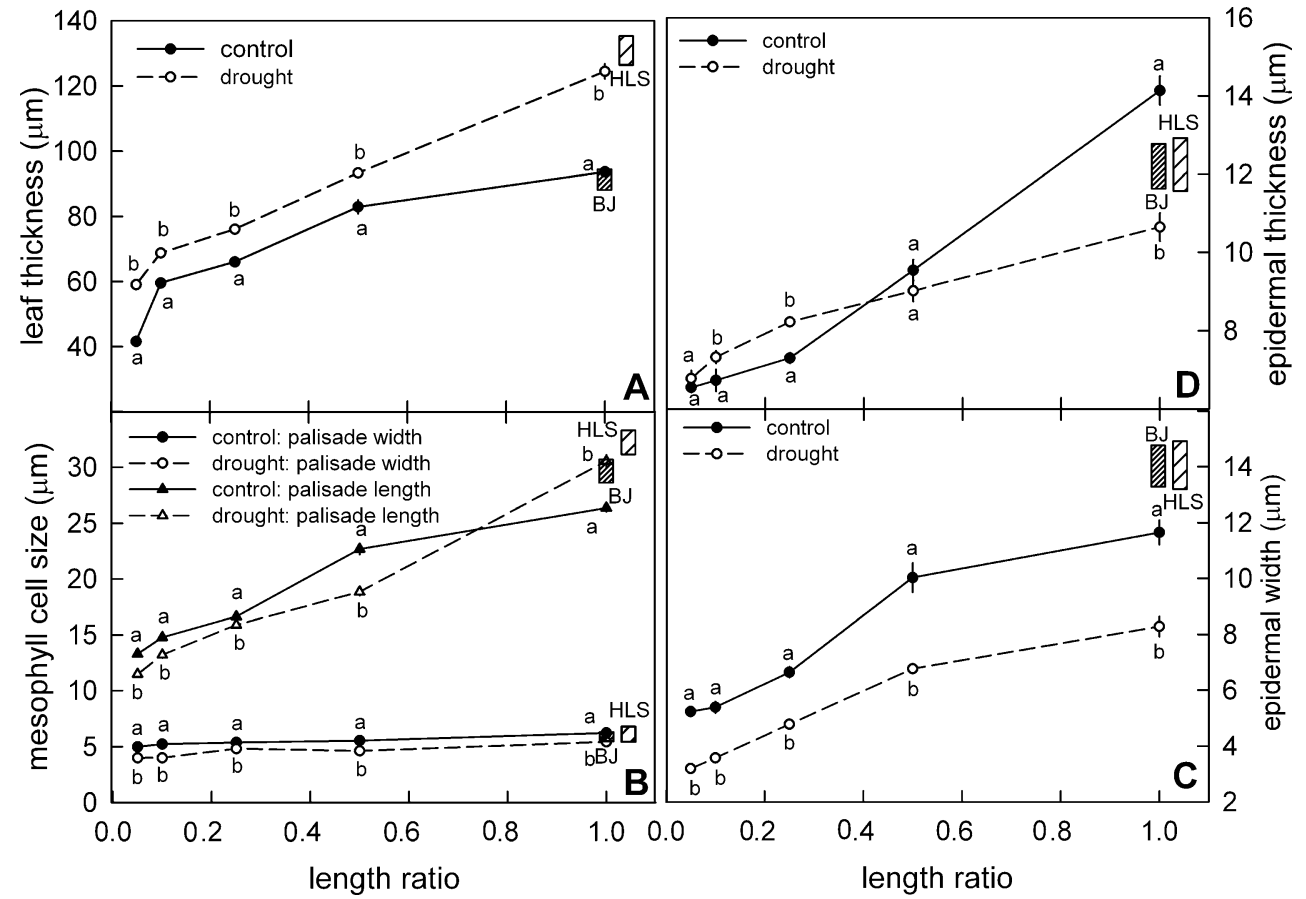


Table 2 Summary of upper epidermal and mesophyll cell number per cross area (number $/ \mathrm{mm}^{2}$ ) at five growth points during leaf development $(5 \%, 10 \%, 25 \%, 50 \%$, and $100 \%$ of final leaf length) in the two treatments

\begin{tabular}{|c|c|c|c|c|c|c|c|c|c|}
\hline \multirow[t]{2}{*}{ Length ratio } & \multicolumn{3}{|c|}{ Epidermal cells } & \multicolumn{3}{|c|}{ First-layer palisade cells } & \multicolumn{3}{|c|}{ Other mesophyll cells } \\
\hline & Control & Drought & $P$ value & Control & Drought & $P$ value & Control & Drought & $P$ value \\
\hline $5 \%$ & $6714 \pm 493 a$ & $4072 \pm 195 b$ & $<0.001$ & $6008 \pm 601 \mathrm{a}$ & $4172 \pm 41 b$ & $<0.001$ & $24537 \pm 925 \mathrm{a}$ & $16323 \pm 1299 b$ & $<0.001$ \\
\hline $10 \%$ & $4195 \pm 227 \mathrm{a}$ & $4367 \pm 171 \mathrm{a}$ & 0.11 & $4299 \pm 192 a$ & $4327 \pm 208 \mathrm{a}$ & 0.26 & $17796 \pm 1233 a$ & $18352 \pm 891 \mathrm{a}$ & 0.093 \\
\hline $25 \%$ & $4137 \pm 124 a$ & $3721 \pm 160 \mathrm{a}$ & 0.08 & $3937 \pm 86 a$ & $3614 \pm 110 \mathrm{a}$ & 0.41 & $16756 \pm 707 \mathrm{a}$ & $15344 \pm 569 \mathrm{a}$ & 0.078 \\
\hline $50 \%$ & $2088 \pm 180 \mathrm{a}$ & $2879 \pm 121 b$ & $<0.01$ & $2752 \pm 121 \mathrm{a}$ & $3171 \pm 93 b$ & $<0.01$ & $10307 \pm 508 \mathrm{a}$ & $12849 \pm 397 b$ & $<0.01$ \\
\hline $100 \%$ & $1348 \pm 82 a$ & $784 \pm 46 b$ & $<0.01$ & $1858 \pm 41 \mathrm{a}$ & $1747 \pm 88 \mathrm{a}$ & 0.091 & $5756 \pm 245 a$ & $5299 \pm 267 a$ & 0.082 \\
\hline
\end{tabular}

Values are means \pm SE. Different letters behind the values indicate significant differences between treatments $(P<0.05)$

contribution of $E$ to $\Psi_{1}$ is inversely proportional to the path length resistance $\left(R_{\mathrm{p}}\right)$ for water flow from the soil to the growing leaves. Also, leaves higher up in a canopy tend to have higher $R_{\mathrm{p}}$ values. So $h$ and $I$ are far from being independent from each other if we accept the hypothesis that growth rate is regulated by $\Psi_{\mathrm{w}}$ through some kind of Lockhart growth equation.

The present study was done to evaluate to what extent the morphological plasticity observed in adult Robinia leaves along tree height (paper I of this series) were attributable mainly to height-driven hydraulic constraints. In this experiment, the sole difference between treatments was a water potential difference comparable to that previously measured between the top and bottom of the crown of 20-m-tall Robinia trees growing in a temperate sub-humid site and in a temperate arid site (BJ and HLS sites, respectively, in paper I of this series). Our data showed that this imposed hydraulic constraint resulted in a significant variation in leaf morphological characteristics, such as smaller leaf area, higher LMA, and density (Figs. 1 and 2). These changes followed the same trend previously observed between leaves developed at the bottom versus the top of the canopy of adult trees (paper I of this series). Our data are in agreement with a study performed on Quercus rubra, which conclude that hydraulic limitations imposed by crown placement determine final size and shape of leaves Zwieniecki et al. (2004). This conclusion was bolstered by the assertion that irradiance, air temperature, and relative humidity were similar at the top and bottom of the crowns $(h<18 \mathrm{~m})$ throughout the period of leaf growth until leaf size reached more than $95 \%$ of final leaf size (Zwieniecki et al. 2004).

In addition to the main objective to assess the role of hydraulic limitations in the resulting leaf morpho-anatomical characteristics, our study also sought to gain a better understanding of the mechanisms underlying leaf morphological plasticity. One important mechanism to understand is the biomechanics of leaf growth and how this responds to water stress. In most previous studies, correlations were performed between final mature leaf morphology and $\Psi_{\mathrm{w}}, h$, and $I$ parameters without specific regard to documenting $\Psi_{\mathrm{w}}$, $h$, and $I$ when leaves were growing nor the tempo of growth. Our study is unique in that it addresses the tempo of growth, controls $\Psi_{\mathrm{w}}$ during leaf growth, and documents how the temporal growth process results in different morphologies. The mechanisms resulting in plasticity of leaf morphology can potentially involve both cell division and cell enlargement. Water stress affects leaf growth at the cellular level in either of two growth phases. During the first growth phase (before $25 \%$ of final leaf length), leaf growth is the consequence of coordinated cell division and tissue expansion (Pothig and Sussex 1985), which is reflected by low $G R$ and high $R G R$ (Fig. 1). Inhibition of cell division in younger leaves (i.e., before $5 \%$ of final leaf length) results in fewer epidermal and mesophyll cells per leaf under water stress (Table 2). During the second growth phase, leaf growth mainly depends on cell expansion (Granier and Tardieu 1998). We found that both palisade mesophyll and epidermal cell size were significantly reduced under water stress (Fig. 4). Smaller final leaf size under water stress is the consequence of lowered leaf growth rate despite prolonged growth duration in stressed versus control plants (Fig. 1). Increased leaf growth duration under water deficit is usually suggested to be related to cell division in the first growth phase (Aguirrezabal et al. 2006; Pereyra-Irujo et al. 2008). Reduced leaf growth is mainly attributed to smaller $G R$, which is closely associated with lower cell expansion during the second phase (Fig. 1; Pereyra-Irujo et al. 2008). Overall, our data suggest that water stress affects leaf morphology via its effect on both cell division and expansion.

The activity of cell division and expansion during leaf growth might be reflected from the temporal changes of LMA and density (Fig. 2). After leaf emergence, before leaf rapid expansion, mesophyll cell number increases (Table 2) and new cell wall buildup may result in increase of LMA and leaf density. During leaf rapid expansion, cell volume expansion (Fig. 4) leads to the decline of leaf density, while 
secondary cell wall deposition at maturity might lead to a further increase in leaf density (Jurik 1986).

During leaf growth, LMA and density were significantly higher under water stress, which can be explained by the difference in cell number and cell size during leaf growth observed between treatments (Table 2; Fig. 4). At $5 \%$ of final leaf length, water stress inhibits cell division and in turn cell number per cross area was significantly smaller under water stress than controls. At $10 \%$ and $25 \%$ final length, total cell number per across area is not significantly different between treatments (Table 2), but leaf density and LMA in water-stressed plants were still higher than in controls. The one reason might be that cell wall properties are changed under water stress, which could be reflected by cell wall lower extensibility $m$ and higher yield threshold $Y$ in Eq. 2 (Matthews et al. 1984; paper III of this series). The other more likely reasons are explained in Zhang et al. (2011). Final leaf density and LMA values found in this study were smaller than those observed in the field (paper I of this series). Two possible reasons may account for these differences: (1) field trees experience five times higher maximum light intensities than in our controlled environment experiments, and it is known that leaves respond to high light by growing thicker mesophyll tissue (more layers of palisade mesophyll cells) to enhance light absorption (Hanson 1917), (2) mature leaves of seedlings may differ from leaves found on adult trees (Piel et al. 2002).

In conclusion, this study suggests that water stress can influence leaf morphology significantly via its effect on the leaf growth process, and the magnitude of the changes are comparable to what we observed in mature Robinia trees (vertical bars in Figs. 2 and 4). Although the $\Psi_{\mathrm{w}}$ values in this study differ quantitatively from the field study on Robinia (paper I of this series), the differences were likely due to factors in Eq. 1 and that measurements were made in summer on mature leaves in the field. The lower midsummer values of $\Psi_{\mathrm{w}}$ were likely because of lower $\Psi_{\text {soil }}$ higher $E$ and higher $R_{\mathrm{p}}$ than the values in spring. The temporal changes of leaf and cell properties during leaf growth were different between the two treatments. The impact of water stress on growth parameters in the Lockhart growth equation (Lockhart 1965) will be addressed in the series paper III.

\begin{abstract}
Acknowledgements The authors thank Bruce Alexander, Greenhouse Manager of ALES Faculty, University of Alberta, for his valuable support. MTT wishes to thank the United States Forest Service for salary support while working at the University of Alberta, which made this study possible. YXZ wishes to thank the China Scholarship Council for travel costs to Canada and thanks to Tsinghua University for granting leave from normal study to conduct research at University of Alberta as a jointly trained PhD student for 18 months.
\end{abstract}

Funding This study was supported by the National Natural Science Foundation of China (30070637).

\section{References}

Aguirrezabal L, Bouchier-Combaud S, Radziejwoski A, Dauzat M, Cookson SJ, Granier C (2006) Plasticity to soil water deficit in Arabidopsis thaliana: dissection of leaf development into underlying growth dynamic and cellular variables reveals invisible phenotypes. Plant Cell Eviron 29:2216-2227. doi:10.1111/ j.1365-3040.2006.01595.x

Cavaleri MA, Oberbauer SF, Clark DB, Clark DA, Ryan MG (2010) Height is more important than light in determining leaf morphology in a tropical forest. Ecology 91:1730-1739. doi:10.1890/09-1326.1

Ellsworth DS, Reich PB (1993) Canopy structure and vertical patterns of photosynthesis and related leaf traits in a deciduous forest. Oecologia 96:169-178. doi:10.1007/BF00317729

England JR, Attiwill PM (2006) Changes in leaf morphology and anatomy with tree age and height in the broadleaved evergreen species, Eucalyptus regnans F. Muell. Trees 20:79-90. doi:10.1007/s00468-005-0015-5

Granier C, Tardieu F (1998) Spatial and temporal analyses of expansion and cell cycle in sunflower leaves. A common pattern of development for all zones of a leaf and different leaves of a plant. Plant Physiol 116:991-1001. doi:10.1104/ pp.116.3.991

Granier C, Tardieu F (1999) Water deficit and spatial pattern of leaf development. Variability in responses can be simulated using a simple model of leaf development. Plant Physiol 119:609-620. doi:10.1104/pp.119.2.609

Granier C, Tardieu F (2009) Multi-scale phenotyping of leaf expansion in response to environmental changes: the whole is more than the sum of parts. Plant Cell Eviron 32:1175-1184. doi:10.111/j.13653040.2009.01955.x

Hanson H (1917) Leaf-structure as related to environment. Am J Bot 4:533-560

Hikosaka K, Terashima I, Katoh S (1994) Effects of leaf age, nitrogen nutrition and photon flux-density on the distribution of nitrogen among leaves of a vine grown horizontally to avoid mutual shading of leaves. Oecologia 97:451-457. doi:10.1007/ BF00325881

Jurik TW (1986) Temporal and spatial patterns of specific leaf weight in successional northern hardwood tree species. Am J Bot 73:1083-1092. doi:10.2307/i319560

Koch GW, Sillett SC, Jennings GM, Davis SD (2004) The limits to tree height. Nature 428:851-854. doi:10.1038/nature02417

Lecoeur J, Wery J, Turc O, Tardieu F (1995) Expansion of pea leaves subjected to short water deficit: cell number and cell size are sensitive to stress at different periods of leaf development. J Exp Bot 46:1093-1101. doi:10.1093/jxb/46.9.1093

Lockhart JA (1965) An analysis of irreversible plant cell elongation. J Theoret Biol 8:264-275. doi:10.1016/0022-5193(65)90077-9

Marshall JD, Monserud RA (2003) Foliage height influences specific leaf area of three conifer species. Can J Forest Res 33:164-170. doi: $10.1139 / \mathrm{x} 02-158$

Matthews MA, Van Volkenburgh E, Boyer JS (1984) Acclimation of leaf growth to low water potentials in sunflower. Plant Cell Environ 7:199-206. doi:10.1111/1365-3040.ep11614641

Meinzer FC, Bond BJ, Karanian JA (2008) Biophysical constraints on leaf expansion in a tall conifer. Tree Physiol 28:197-206. doi:10.1093/treephys/28.2.197

Oldham AR, Sillett SC, Tomescu MF, Koch GW (2010) The hydrostatic gradient, not light availability drives height-related variation in Sequoia Sempervirens (Cupressaceae) leaf anatomy. Am J Bot 97:1087-1097. doi:10.3732/ajb.0900214

Pereyra-Irujo GA, Velazquez L, Lechner L, Aguirrezabal LAN (2008) Genetic variability for leaf growth rate duration under water 
deficit in sunflower: analysis of responses at cell, organ, and plant level. J Exp Bot 59:2221-2232. doi:10.1093/jxb/ern087

Piel C, Frak E, Roux XL, Genty B (2002) Effect of local irradiance on $\mathrm{CO}_{2}$ transfer conductance of mesophyll in walnut. J Exp Bot 53:2423-2430. doi:10.1093/jxb/erf095

Pothig RS, Sussex IM (1985) The developmental morphology and growth dynamics of the tobacco leaf. Planta 165:158-169. doi:10.1007/bf00395038

Sack L, Melcher PJ, Liu WH, Middleton E, Pardee T (2006) How strong is intracanopy leaf plasticity in temperate deciduous trees? Am J Bot 93:829-839. doi:10.3732/ajb.93.6.829

Tyree MT (1999) Water relations and hydraulic architecture. In: Pugnaire FI, Valladares F (eds) Handbook of functional plant ecology. Marcel Dekker, New York, pp 222-265
Tyree MT, Zimmermann MH (2002) Xylem structure and the ascent of sap. Springer, Berlin

Woodruff DR, Bond BJ, Meinzer FC (2004) Does turgor limit growth in tall trees? Plant Cell Environ 27:229-236. doi:10.1111/j.13653040.2003.01141.x

Zhang Y-X, Equiza MA, Zheng Q-S, Tyree MT (2011) The impact of long-term water stress on relative growth rate and morphology of needles and shoots of Metasequoia glytostroboides seedlings: research toward identifying mechanistic models. Physiol Plant. doi:10.1111/j.1399-3054.2011.01482.x

Zwieniecki MA, Boyce CK, Holbrook NM (2004) Hydraulic limitations imposed by crown placement determine final size and shape of Quercus rubra L. leaves. Plant Cell Environ 27:357-365. doi:10.1111/j.1365-3040.2003.01153.x 